\title{
Contents, Vol. 19, 1980
}

Founded 1897 as 'Monatsschrift filir Psychiatrie und Neurologie',

continued 1957-1967 as 'Psychiatria et Neurologia'

Founders: C. Wernicke and Th. Ziehen

Successors: K. Bonhoeffer (1912-1938), J. Klaesi (1939-1967), E. Grunthal (1953-1967)

Editor-in-Chief:

Editorial Board:

Advisory Board:

H.E. Kaeser, Basel

G.G. Brune, Mịinster

L. Barraquer Bordas, Barcelona

H.P. Ludin, Bern

Associate Editors:
S. Feldman, Jerusalem

J. Droogleever Fortuyn, Groningen

C. Loeb, Genova

P. Huber, Bern

H.-G. Mertens, Wiirzburg

A. Kreindler, Bucharest

H.B. Rieder, Basel

U.K. Rinne, Turku

HJ. Lehmann, Essen

H. vander Eecken, Ghent

C. Pallis, London

P. Passouant, Montpellier

E. Satoyoshi, Tokyo

F. Seitelberger, Vienna

F. Vassella, Bern

W. Tackmann, Basel 
P.O. Box, CH-4009 Basel (Switzerland)

Printed in Switzerland by Thiir AG Offsetdruck,

Pratteln 
No part of this publication may be translated into other languages, reproduced or utilized in any form or by any means, electronic or mechanical, including photocopying, recording, microcopying, or by any information storage and retrieval system, without permission in writing from the publisher.

Contents Vol. 19, 1980

No. 1

Editorial

Protracted Transient Ischemic Attacks

Loeb, C

\section{Original Papers}

Phantom and Amputation Illusions in Paraplegic Patients

Ettlin, T.M.; Seiler, W., and Kaeser, H.E

Conduction of Electrically Elicited Impulses in Peripheral Nerves of Diabetic Patients

Tackmann, W. and Lehman,

A Critical Appraisal of Neuromuscular Stimulation and Electrotherapy in Neurorehabilitation

Merletti, R. and Pinelli, P

Electroencephalography and Computerized Transaxial Tomography in Patients with Temporal Lobe Epilepsy

Scollo-Lavizzari, G. and Balmer, C.

Calcium-Dependent Potassium Transport in Progressive Muscular Dystrophy

Szentistvanyi, I, Jank, $Z$, and Heiner, L ...

Z,-Dopa and the Secretion of Sebum in Parkinsonian Patients

Streifler, M.; Avrami, E., and Rabey, J.M.

The Touch Corpuscles of the Plantar Surface of the Big Toe. Histological and Histometrical Investigations with Respect ${ }^{43}$ to Age

Schimrigk, K. and Ruttinger, $\mathrm{H}$

Pial Arteriolar Reaction to Intravenous Administration of Bencyclane in the Cat

Auer, L. and Trummer, G

Plasma-High-Density Lipoprotein Cholesterol in Epileptics Treated with Various Anticonvulsants

Luoma, P.V.; Myllyla, V.V.; Sotaniemil, E.A.; Lehtinnen, I.A., and Hokkanen, E.J

No. 2

\section{Original Papers}

Cerebral Complication of Antifibrinolytic Therapy in the Treatment of Ruptured Intracranial Aneurysm Animal Experiment and a Review of Literature

Yamaura, A.;Nakamura, T.;Makino, H., and Hagihara, Y

Brain and CSF Proteins in Creutzfeldt-Jakob Disease

Olsson, J.-E.

Posttraumatic Amnesia, Post-Concussional Symptoms and Accident Neurosis

Guthkelch, A.N 
Practical and Theoretical Aspects of Phenytoin Administration. II. Prediction of Plasma Concentration

Driessen, O.; Velde, E.A. van der, and Hoppener, R.J

Distribution of ${ }^{14} \mathrm{C}$-Phenytoin in Rat Purkinje Cells, Cerebellar and Cerebral Neuronal Tissue after a Single Intraperitoneal Injection

Savolainen, H.; livanainen, M.; Elovaara, E., and Tammisto, P

115

Skeletal Findings in Human Neurolathyrism. Is There a Human Osteolathyrism?

Weintroub, S; Cohen, DF.Salama, R. Streifler, M., and Weis,

Polymyositis in Eosinophilic Fasciitis. Review and Case Report

Bjelle, A.; Henriksson, K.-G., and Hofer, P.-A

Book Reviews

No. 3

\section{Original Papers}

Studies on Familial Amyloid Polyneuropathy in Ogawa Village, Japan

Kito, S.; Itoga, E.;Kamiya, K.; Kishida, T., and Yamamura, Y

Medical versus Surgical Treatment of Patients with Cerebrovascular Insufficiency. A Retrospective Comparative Stud

Auer, L.; Gallhofer, B.; Ladurner, G.; Ott, E.; Heppner, F., and Lechner, H ............................................................

Paracetamol (Acetaminophen) versus Acetylsalicylic Acid in Migraine

Tfelt-Hansen, P. and Olesen, J

163

Pathological Findings in One of Two Siblings with Sjogren-Larsson Syndrome

Silva, C.A.; Saraiva, A.; Goncalves, V.; Sousa, G. de; Martins, R., and Cruz, C ................................................ 166

Pituitary Adenomas: Computed Tomography and Clinical Evaluation in a Follow-Up after Surgical Treatment

Muhr, C; Bergstrom, K.; Hugosson, R., and Lundberg, P.0

Computer Tomography in Children with Epilepsy

Ladurner, G.; Fritsch, G.; Sager, W.D.;Iliff, L.D., and Lechner, H ...

Optic Newitis and Meltiple Sclersis. An Int,

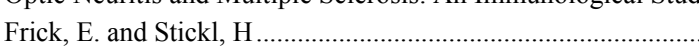

Combination of Multiple Sclerosis and Cerebral Glioblastoma

Lahl, R

Serion in Patients with Parkinson's Disease and Huntington's Chorea

Murri, L.; ludice, A.; Muratorio, A.; Polleri, A.; Barreca, T., and Murialdo, G.............................................................. 198

Familial Muscle Cramps with Autosomal Dominant Transmission

VandenBergh, P.;Bulcke, J.A., and Dom, R

\section{No. 4}

\section{Original Papers}

Lymphomatoid Granulomatosis Manifesting as a Subacute Polyradiculoneuropathy. A Case Report and Review of the Neurological Manifestations Calatayud, T.; Vallejo, A.R.; Dominguez, L.; Sotelo, T.;Pefla, P., and Jimenez, M.. 
Neuropathies Associated with Disorders of Plasmocytes

Noring, L.; Kjellin, K.G., and Siden, A 224

Myokymia in the Course of Peripheral Idiopathic Facial Palsy

Juvarra, G.; Bettoni, L., and Lechi, A

Muscle Nuclear Changes in Myotonic Dystrophy

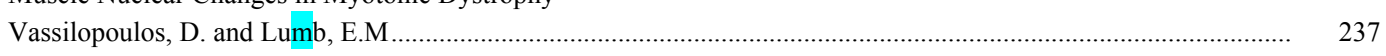

Surface Markers on Lymphocytes from Human Cerebrospinal Fluid. II. Altered Patterns in Subacute Sclerosing Panencephalitis

Manconi, P.E.; Marrosu, M.G.; Cianchetti, C, and Zaccheo, D................................................................................ 24

Serum and Cerebrospinal Fluid Proteins in Tuberculous Meningitis

Guindi, S.;Mansour, M.M.; Girgis, N.I., and Miner, W.F.

Hypokalemic Periodic Paralysis Associated with Multiple Sclerosis

Sadeh, M.; Ohry, A.; Sarova-Pinhas, I., and Braham, J ........................................................................ 252

Aortic Dissection and Paraparesis

Waltimo, O. and Karli, P...

Some Extrapyramidal Motor Signs in Cases of Undifferentiated Amentia

Burt, A.A.; Nagdee, K.A. and James, F.E ........................................................................................................... 258

Histocompatibility Antigens in Alzheimer's Disease. A Preliminary Study

Wilcox, C.B.; Caspary, E.A., and Behan, P.0.......................................................................................... 262

Further Observations with the Erythrocyte-Unsaturated Fatty Acid Test. A Contributions to the Genetics of Multiple Sclerosis Joyce, G. and Field, E.J.

Lead Polyneuropathy of Nonindustrial Origin

Tavolato, B.; Licandro, A.C., and Argentiero, V .

\section{Case Report}

Pure Sensory Polyneuropathy of Herpes Virus Origin Associated with Meningoencephalitis. A Case Report Solzi, P.; Braun, Z., and Pryborkin, V

Book Review

No. 5

\section{Original Papers}

Adrenomyeloneuropathy and Adrenoleukodystrophy in Two Brothers

Martin, J.J.; Dompas, B.; Ceuterick, C, and Jacobs, K

Adult, Metachromatic Leukodystrophy. III. Clinical Course, Final Stages and First Biochemical Results

Seidel, D.;Heipertz, R;Goebel, H.H.; Duensing, I, andPilz, H.f '

Adult Metachromatic Leukodystrophy. IV. Ultrastructural Studies on the Central and Peripheral Nervous System

Goebel, H.H.; Argyrakis, A.; Shimokawa, K.; Seidel, D., and Heipertz, R........................................................ 294

$\mathrm{n}$-Hexane Polyneuropathy. An Occupational Disease of Shoemakers

Rizzuto, N.; De Grandis, D.; Di Trapani, G., and Pasinato, E

Simultaneous Occurrence of Neuralgic Amyotrophy in Three Members of One Family

Martinelli, P. Pazzaglia, P ; Marchiori, L, and Lugaresi, E.

$\mathrm{Ml}$

Effects of Cerebral Gangliosides in the Alcoholic Polyneuropathies

Mamoli, B.;Brunner, G.;Mader, R., and Schanda, H

A Case of Facial Diplegia following Herpes zoster ophthalmicus

Shoji, H.; Hirose, K.; Uono, M., and Koya, M

EEC Findings and Sleep Deprivation

Tartara, A.; Moglia, A.; Manni, R., and Corbellini, C

Neurologic Symptoms of Basal Cell Nervus Syndrome

Esser, R. and Bohnert, B

Loss of Striatal Neurons in Parkinson's Disease: Cytometric Study

Bugiani, 0.; Perdelli, F.; Salvarani, S.; Leonardi, A., and Mancardi, G.L

\section{Original Papers}

Predictability of Phenytoin Serum Levels by Nomograms and Clinicians

Vozeh, S.; Koelz, A.; Martin, E.; Magun, H.; Scollo-Lavizzari, G., and Follath, F .................................................. 345 Practical and Theoretical Aspects of Phenytoin Administration. I. Relationship between Dose and Plasma Concentration Driessen, O.; Hoppener, R.J., and Velde, E.A. van der 
Exposure to Industrial Solvents and Brain Atrophy. A Retrospective Study of Pneumoencephalographic Findings among 37 Patients with Exposure to Industrial Solvents

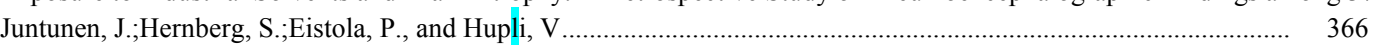

Angiographical Findings and Risk Factors in Cerebral Ischaemia. A Retrospective Study

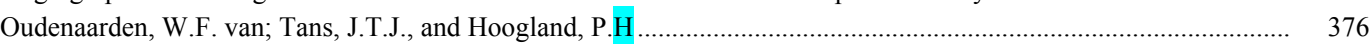

Motor Evaluation in Vascular Hemiplegia

Demeurisse, G.; Demol, O., and Robaye, E ................................................................................................... 382

Morphological Basis of Adie's Syndrome

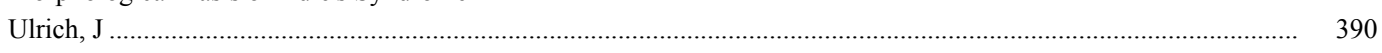

Auditory Brain Stem Evoked Potentials in Patients with Multiple Sclerosis. Investigations in Patients with Different Degrees of Diagnostic Probability

Tackmann,W.; Strenge, H.; Barth, R., and Sojka-Raytscheff, A

Central Somatosensory Conduction Time in Diagnosis of Multiple Sclerosis

Strenge, H.; Tackmann, W.; Barth, R., and Sojka-Raytscheff, A .......................................................................... 402

Electrospinogram of the Rabbit. Monitoring of the Spinal Conduction in Acute Cord Lesions versus Clinical Observation

Rossini, P.M.; Greco, F.;De Palma, L., and Pisano, L ...................................................................................... 409

Motor Neuron Disease following Poliomyelitis. Bioptic Study of Five Cases

Palmucci, L.; Bertolotto, A.; Doriguzzi, C; Mongini, T., and Schiffer, D..

414

\section{Case Report}

Peripheral Neuropathy due to Gasoline Sniffing. A Case Report

Galassi, R.; Montagna, P.;Pazzaglia, P.;Cirignotta, F., and Lugaresi,E

Author Index

422

Subject Index 